
\title{
IJSED and Development
}

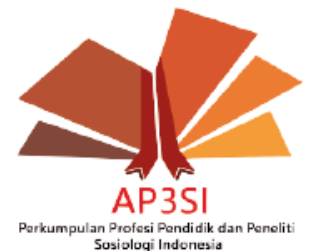

ISSN 2685-483X

Volume 1, Issue 2, Juli-Desember 2019

Halaman 96-105

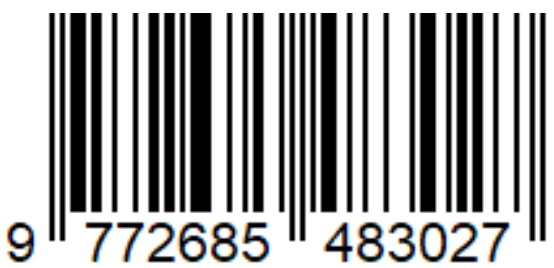

\section{Perubahan Sosial di Tosari (Studi Kasus Lunturnya Folklore Masyarakat Desa Tosari, Kecamatan Tosari, Kabupaten Pasuruan)}

\author{
Harwan Dharma Aji Manggala \\ Universitas Sebelas Maret Surakarta
}

\begin{tabular}{ll}
\hline Kata Kunci & Abstrak \\
\hline Perubahan Sosial & $\begin{array}{l}\text { Perubahan sosial terjadi di setiap lapisan masyarakat secara disadari maupun } \\
\text { tidak. Beberapa hal yang menyebabkan perubahan sosial adalah adanya }\end{array}$ \\
Folklore & $\begin{array}{l}\text { penemuan baru, adanya revolusi, dan modernisasi yang terjadi di suatu } \\
\text { tempat. Perubahan sosial dirasakan di Desa Tosari ditandai dengan lunturnya } \\
\text { folklore yang mempunyai hubungan dengan kepercayaan maupun ritual }\end{array}$ \\
& $\begin{array}{l}\text { yang mereka miliki. Penelitian ini dilakukan untuk mengetahui bagaimana } \\
\text { Kroses lunturnya Folklore dan mengapa Folklore di masyarakat Desa Tosari }\end{array}$ \\
& $\begin{array}{l}\text { Tengalami pelunturan. Penelitian ini dilakukan di Desa Tosari, Kecamatan } \\
\text { dengan pendekatan studi kasus menggunakan teknik pengumpulan data }\end{array}$ \\
& $\begin{array}{l}\text { purposive sampling. Lunturnya folklore masyarakat Desa Tosari dimana } \\
\text { menjadi tempat tinggal Suku Tengger terjadi karena adanya pengaruh } \\
\text { gagasan baru yaitu agama Islam yang masuk ke dalam masyarakat tersebut. } \\
\text { Agama Islam menjadi agama mayoritas di Desa Tosari. Integrasi menjadi } \\
\text { kunci dalam perubahan sosial ini. }\end{array}$ \\
\hline Diterima & 28 Juli 2019 \\
\hline Review & 15 Agustus 2019 \\
\hline Revisi & 29 Agustus 2019 \\
\hline Penerimaan & 8 Oktober 2019 \\
\hline Copyedit & 4-9 Desember 2019 \\
\hline 10 Desember 2019
\end{tabular}




\section{IJSED \\ Indonesian Journal of Sociology, Education, and Development}

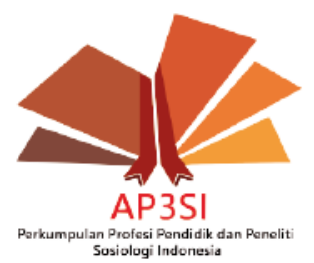

ISSN 2685-483X

Volume 1, Issue 2, Juli-Desember 2019

Pages 96-105

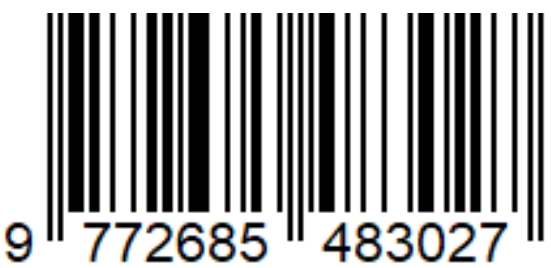

\section{Social Change in Tosari (Case Study of the Local Folklore Diminishment in Desa Tosari, Kecamatan Tosari, Kabupaten Pasuruan)}

Harwan Dharma Aji Manggala

Universitas Sebelas Maret Surakarta

\begin{tabular}{ll}
\hline Keywords & Abstract \\
\hline Social Change & $\begin{array}{l}\text { Social changes occur in every level of society caused by the community } \\
\text { itself consciously or not. Some factors that cause social change are new } \\
\text { discoveries, a revolution, and modernization. Social change felt in Tosari } \\
\text { Village was marked by faded folklore which has a relationship with their } \\
\text { beliefs and rituals. This research conducted to find outhow the fading out } \\
\text { processes andwhy Folklore in the Tosari community fading away. Research } \\
\text { was conducted in the Village of Tosari, Sub-district of Tosari, Pasuruan } \\
\text { Regency, East Java Province using qualitative research with case study } \\
\text { approach. Using a purposive sampling data was collected. Result of this } \\
\text { research are folklore fading of the Tengger tribe occurred because ofnew } \\
\text { ideas, namely Islam, which entered thecommunity. Islam is the majority } \\
\text { religion in Tosari Village. Integration is the key to this social change. }\end{array}$ \\
\hline 28 Juli 2019 \\
\hline Review & 15 Agustus 2019 \\
\hline Revision & 29 Agustus 2019 \\
\hline Acceptance & 8 Oktober 2019 \\
\hline Copyediting & 4-9 Desember 2019 \\
\hline Publication & 10 Desember 2019 \\
\hline
\end{tabular}




\section{Pendahuluan}

Perubahan dalam masyarakat pasti terjadi disadari atau tidak, meskipun terkadang perubahan di dalamnya tidak selamanya mencolok atau sangat berpengaruh terhadap kehidupan luas. Terdapat perubahan yang bersifat sangat lambat, ada pula cepat dan mencakup aspek-aspek yang luas. Perubahan tersebut akan terlihat dan dapat ditemukan oleh seseorang yang mau meneliti susunan dan kehidupan suatu masyarakat dalam kurun waktu tertentu dan dibandingkan dengan susunan dan kehidupan masyarakat tersebut pada masa lampau. Perubahan sosial yang terjadi dalam masyarakat tidak selamanya akan berdampak kepada kemajuan, namun dampak yang ditimbulkan dapat mengakibatkan kemunduran. Masyarakat memandang sebuah kemajuan yang terjadi di lingkungannya merupakan sebuah keberhasilan. Tetapi jika ditelaah lebih dalam lagi, perubahan tersebut bisa berbanding terbalik dengan sistem sosial yang juga mengalami perubahan dan dapat dirasakan oleh masyarakat.

Perubahan yang terjadi pada masyarakat di dunia ini merupakan gejala yang normal, pengaruhnya merambat dengan cepat ke bagian-bagian lain dari dunia, antara lain berkat adanya komunikasi modern.

Pengaruh perubahan terjadi karenaadanya perkembangan teknologikomunikasi yang menyebabkan masyarakat dalam mengakses segala media informasi yang ada. Masyarakat yang tinggal di pedesaan umumnya bermata pencaharian sebagai petani. Pertemuan yang terjadi antara masyarakat agraris dan sektor teknologi akan melahirkan perubahan-perubahan yang relatif homogen menuju yang relatif kompleks, baik itu dalam pola tingkah laku, pranata sosial ataupun sistem sosial dalam sebuah masyarakat. Pertemuan dua bentuk kebudayaan tersebut akan melahirkan kebudayaan baru, baik pada pihak penerima ataupun kepada pihak yang akan memberi pengaruh.

Industri pariwisata juga terkena dampak dari adanya kemajuan teknologi tersebut. Adapun pengaruh kemajuan tersebut terhadap perubahan sosial menurut temuan penelitian dari Suwantoro (2004, 26-27) perihal manfaat dalam pembangunan pariwisata. Yaitu dalam bidang ekonomi meningkatkan kesempatan kerja dan berusaha, baik secara langsung maupun tidak langsung dan meningkatkan dan memeratakan pendapatan masyarakat melalui belanja wisatawanbaiklangsungmaupuntidaklangsungmelaluidampakberganda(multipliereffect). Jadi, industri pariwisata mampu mempengaruhi struktur sosial dari masyarakat dalam bidang ekonomi. Kemajuan pariwisata mempengaruhi perubahan sosial di masyarakat. Terkait dengan penelitian perubahan sosial dalam pariwisata. Indonesia memiliki industri pariwisata yang terus meningkat. Data statistik Jumlah kunjungan wisatawan mancanegara atau wisatawan mancanegara ke Indonesia Desember 2018 naik 22,54 \% dibanding jumlah kunjungan pada Desember 2017, yaitu dari 1,15 juta kunjungan menjadi 1,41 juta kunjungan. Begitu pula, jika dibandingkan dengan November 2018, jumlah kunjungan wisatawan mancanegara pada Desember 2018 mengalami kenaikan sebesar 21,43\% (Badan Pusat Statistik, 2019). Industri pariwisata di Indonesia tidak hanya berfokus pada wisata alam, melainkan terdapat juga wisata dengan unsur budaya. Salah satu contoh wisata budaya di Indonesia adalah wisata budaya Suku Tengger yang terletak di lereng Gunung Bromo.

Gunung Bromo merupakan objek wisata yang berada dalam empat wilayah, yaitu Kabupaten Probolinggo, Kabupaten Pasuruan, Kabupaten Lumajang, dan Kabupaten Malang. Gunung Bromo menjadi wisata andalan di Kabupaten Pasuruan. Gunung Bromo memiliki ketinggian 2.329 meter di atas permukaan laut. Bagi penduduk Suku Tengger, Gunung Bromo dipercaya sebagai gunung suci. Setahun sekali masyarakat Suku Tengger memperingati upacara Yadnya Kasada. Upacara ritual ini dilakukan di sebuah pura yang berada di kaki Gunung Bromo dan setelah itu dilanjutkan ke puncak Bromo untuk melempar seserahan hasil bumi yang didapat oleh masyarakat selama setahun kalender Suku Tengger. Mitos juga berhubungan dengan perasaan percaya pada lingkup primitif mengenai kehidupan alam gaib bersifat irasional.

Suku Tengger memiliki mitos tersendiri yang dipercaya oleh masyarakatnya. Mitos di Suku Tengger berfungsi sebagai pengangkat dan merumuskan kepercayaan, melindungi dan memperkuat moralitas, menjalankan ritual yang ada, dan sebagai kontrol sosial di masyarakat. Banyak mitos yang menjadi peraturan di masyarakat Suku Tengger dan hal itu menjadi pegangan untuk menjalankan kehidupannya. Salah satunya adalah folklore Gedhang Ayu. Upacara perkawinan Walagara termasuk 
dalam kebudayaan adat Suku Tengger. Dalam upacara perkawinan tersebut terdapat folklore yang dipercayai oleh masyarakat bahwa adanya pengaruh hal gaib (Bahureksa) yang menjadi kontrol dalam upacara tersebut. Penurunan pelaksanaan upacara Walagara mengindikasikan bahwa terjadi pelunturan folklore dalam upacara Suku Tengger. Melihat fenomena ini terjadi di desa Tosari. Peneliti tertarik untuk mencari tahu apakah mitos dalam bentuk folklore di desa Tosari juga terpengaruh dengan adanya perubahan sosial.

Zaman semakin maju, segala aspek kehidupan dipermudah dengan adanya perkembangan di berbagai aspek tentu memberi dampak juga dalam bidang ekonomi, sosial, maupun budaya di Desa Tosari Kecamatan Tosari Kabupaten Pasuruan. Dimana Desa Tosari adalah termasuk daerah yang mempunyai keuntungan yang banyak dalam berbagai sektor. Desa Tosari terletak di lereng Gunung Bromo. Oleh karena itu, Desa Tosari juga merupakan salah satu daerah Suku Tengger. Karena berada di lereng gunung kesuburan tanahnya pun terjamin. Banyak hasil bumi yang sudah dihasilkan oleh daerah ini. Sektor pertaniannya dalam produksi sayur sangat besar. Selain itu Gunung Bromo sendiri merupakan objek wisata yang sudah diakui baik secara nasional maupun internasional. Desa Tosari merupakan salah satu akses untuk menuju ke Gunung Bromo. Hal ini menyebabkan sektor pariwisata di Desa Tosari ini juga ikut maju.

\section{Kajian Literatur}

Penemuan-penemuan baru di bidang teknologi, terjadinya revolusi, modernisasi dan seterusnya yang terjadi di suatu tempat, dengan cepat dapat diketahui oleh masyarakat lain yang letaknya jauh dari tempat tersebut. Kemajuan ini pada awalnya akan menyebabkan disorganisasi dalam masyarakat, apalagi yang menyangkut nilai dan norma yang ada dalam masyarakat, dimana masyarakat yang bersangkutan belum siap berubah (Ellya Rosana, 2011).

Kemajuan dalam bidang teknologi komunikasi tersebut menyebabkan efek domino bagi beberapa aspek. Antara lain dalam bidang pariwisata. Perkembangan pariwisata dapat menimbulkan perubahan yang berdampak baik maupun buruk. Namun, hal yang harus dicermati adalah perubahan yang berdampak buruk. Fakta yang muncul dari perkembangan pembangunan pariwisata yang dapat memberikan dampak kepada perubahan sosial di masyarakat. Berbagai masalah muncul dari perkembangan pariwisata yang mengakibatkan perubahan sosial di masyarakat seperti gaya hidup, sikap atau perilaku, nilai dan norma yang ditunjukkan oleh anggota masyarakat yang telah keluar atau berubah dari nilai dan norma yang berlaku sebelumnya (Nugraha Hilman, dkk, 2015).

Kebudayaan bisa menjadi faktor pendorong daya tarik wisata. Salah satu unsur kebudayaan adalah mitos. Mitos adalah cerita suatu bangsa tentang dewa dan pahlawan zaman dahulu yang mengandung penafsiran tentang asal- usul semesta alam, manusia, dan bangsa itu sendiri yang mengandung arti mendalam yang diungkapkan dengan cara gaib (Kamus Besar Bahasa Indonesia, 1999: 660). Mitos juga berhubungan dengan perasaan percaya pada lingkup primitif mengenai kehidupan alam gaib bersifat irasional. Suku Tengger mempunyai beragam kebudayaan baik itu mitos maupun ritual adat. Salah satu contoh kebudayaan yang ada di masyarakat suku Tengger adalah Walagara. Walagara merupakan upacara adat perkawinan adat yang dipercayai oleh masyarakat suku Tengger di Desa Tosari dengan tujuan pemberitahuan kepada roh (Bahu Rekso) atas adanya suatu perkawinan yang ada di desa tersebut. Namun pada saat ini intensitas pelaksanaan upacara Walagara mengalami penurunan (Nena Puji, 2017: 72).

Perubahan tidak dapat dihindari dalam kehidupan manusia, maka berkembanglah kajian sosiologi mengenai perubahan sosial. Perubahan sosial dalam ilmu sosiologi mengkaji tentang perubahanperubahan yang terjadi dalam kehidupan masyarakat dalam segala aspeknya. Memang terdapat perbedaan di antara perubahan sosial dengan perubahan budaya. Perubahan sosial meliputi perubahan dalam segi struktur sosial yang ada dalam masyarakat, seperti perubahan distribusi kelompok usia, tingkat kelahiran penduduk, pendidikan, penurunan kadar rasa kekeluargaan, dan informalitas antar tetangga karena adanya perpindahan dari desa ke kota, serta persebaran penduduk. Sedangkan perubahan budaya meliputi penambahan kata baru dalam suatu bahasa, perubahan konsep tata susila dan moralitas, perubahan seni, sistem ide yang disepakati oleh masyarakat yang mencakup aturan maupun norma yang digunakan dalam pegangan dalam kehidupan bermasyarakat, teknologi, selera dan rasa keindahan (Lauer, Robert H., 2003: 72) 
Menurut Wilbert Moore (Garna, 1992: 4) perubahan sosial sebagai perubahan penting dalam struktur sosial seperti nilai, norma, maupun fenomena kultural. Perubahan sosial bukan merupakan gejala modern tetapi merupakan hal yang universal dalam kehidupan manusia. Robert $\mathrm{H}$. Lauer (Garna, 1992: 8-9) mengartikan perubahan sosial sebagai konsep inklusif yang menunjuk pada perubahan gejala sosial berbagai tingkat kehidupan manusia, dari mikro hingga makro.

Memperhatikan perubahan sosial, dapat dipahami pula menggunakan teori Fungsional Struktural dari Parsons dengan skema AGIL yaitu Adaptation, Goal Attainment, Integration, dan Latency. Proses perubahan sosial yang menyebabkan lunturnya folklore di masyarakat Suku Tengger terjadi karena adanya adaptasi, pencapaian tujuan, integrasi, dan latensi hal baru di dalam masyarakat tersebut. Masyarakat Suku Tengger di Desa Tosari mengalami adaptasi dengan masyarakat pendatang. Masyarakat pendatang membawa kebudayaan baru yang mampu dikomunikasikan dan dapat diterima oleh masyarakat asli. Kegiatan ekonomi dan juga kepercayaan menjadi unsur kebudayaan baru yang dibawa oleh masyarakat pendatang. kompleksitas mata pencaharian dan berkembangnya agama Islam di Desa Tosari menjadi pencapaian tujuan dalam sebuah perubahan sosial. Dalam proses tersebut terdapat pula integrasi yang ada di dalamnya. Integrasi menjadi penting dalam adanya perubahan dalam masyarakat Desa Tosari, karena di dalam integrasi terdapat komunikasi yang menyebabkan pertukaran informasi atau bahkan budaya bagi masyarakat asli maupun pendatang. Integrasi di Desa Tosari terjadi di beberapa setting tempat, seperti pasar yang menjadi pusat kegiatan ekonomi, dan juga tempat ibadah umat Islam yang digunakan untuk berdakwah. Dalam kegiatan tersebut terdapat pula pemeliharaan pola yang diharapkan mampu mempertahankan pola-pola budaya yang ada. Seperti dalam kegiatan ekonomi khususnya dalam industri pariwisata, terdapat paguyuban hardtop yang memelihara pola baru dalam hal ekonomi.

\section{Metode Penelitian}

Metode yang digunakan dalam penelitian adalah kualitatif dengan pendekatan studi kasus yang kemudian dianalisis dengan menggunakan teori. Teknik yang digunakan dalam pengambilan informan menggunakan teknik purposive sampling. Lokasi dalam penelitian ini adalah Desa Tosari, kecamatan Tosari, Kabupaten Pasuruan di Provinsi Jawa Timur. Informan dalam penelitian ini adalah masyarakat yang terbagi dalam Suku Tengger dan merupakan anggota dari suku tersebut. Penelitian ini menggunakan teknik pengumpulan data yang digunakan dalam penelitian ini adalah observasi, wawancara, dan juga dokumen. Analisis data dilakukan dengan menggunakan kaidah penelitian secara kualitatif dengan memperhatikan reduksi data, matrikulasi dan triangulasi data yang dilakukan beserta dengan penulisan tulisan.

\section{Temuan dan Pembahasan}

Hampir semua perubahan besar mencakup aspek sosial dan budaya. Walaupun perubahan sosial dibedakan dari perubahan budaya tetapi pembahasan yang dibahas perubahan sosial tidak akan mencapai suatu pengertian yang benar tanpa harus mengaitkannya dengan perubahan budaya. Oleh karena itu, dalam penggunaan kedua istilah tersebut perbedaan di antaranya tidak terlalu diperhatikan.

Dalam kompleksitas bermasyarakat terdapat bermacam-macam sudut pandang. Ada kelompok yang mempunyai rasa membangun di mana selalu menginginkan adanya kemajuan dengan adanya pemberontakan sesuai dengan tuntutan zaman. Ada pula kelompok yang mempunyai keyakinan bahwa di kemudian hari terdapat kehidupan yang lebih baik sehingga mereka selalu berhati-hati dalam membawa arus masyarakat cenderung untuk maju dan berubah. Namun ada juga masyarakat dalam golongan yang seolah-olah tidak peduli dengan keadaan lingkungan.

Kebudayaan tidak akan terlepas dari kehidupan manusia. Oleh karena itu suatu kebudayaan cocok dijadikan sebagai objek sosiologi. Kebudayaan terus berkembang seiring berjalannya waktu beriringan dengan perubahan yang terjadi di masyarakat itu sendiri. Seperti halnya yang terjadi di Desa Tosari dalam pemaknaan ritual Gedhang Ayu yang di dalamnya terdapat folklore yang seharusnya dapat digunakan untuk memberi perasaan takut jika suatu ritual itu tidak dilakukan. Ide atau pandangan kebudayaan baru mampu mempengaruhi kebudayaan sebelumnya. Tentu 
kebudayaan yang berubah tersebut tidak terlepas dari perubahan yang terjadi pada masyarakat pemilik kebudayaan itu sendiri.

Proses Adaptation ( Adaptasi ) dalam masyarakat Desa Tosari berdampak dalam segi ekonomi, masyarakat tidak hanya memiliki satu mata pencaharian yaitu sebagai petani, namun telah berubah menjadi lebih kompleks, ada yang berdagang di pasar, maupun pemandu wisata. Dualisme mata pencaharian menjadi hal yang wajar di Desa Tosari. Proses Adaptation ( Adaptasi ) di Desa Tosari berkembang dengan adanya kemajuan teknologi. Beberapa warga

memanfaatkan teknologi tersebut untuk berjualan, memesan penginapan, maupun pemesanan pemandu wisata secara online. Meskipun di Desa Tosari masih kesulitan dalam mendapatkan signal provider telekomunikasi. Namun warga Tosari berinisiatif dengan memasang WiFi hampir di setiap tempat strategis. Seperti warung makan, toko suvenir, kantor pemerintahan, bahkan ada yang sengaja memasang untuk rumah pribadi.

Proses Adaptation (Adaptasi) tidak hanya seputar teknologi, namun dalam hal kepercayaan pun juga. Sebelumnya warga Desa Tosari mayoritas beragama Siwa-Budha. Agama ini cenderung dekat dengan aliran kepercayaan. Maka pada masa konflik PKI tahun 1965, banyak warga Tengger yang mengganti agamanya menjadi Hindu maupun Islam. Menjamurnya agama Islam di Desa Tosari juga dipengaruhi oleh warga di luar daerah. Banyak kegiatan berbasis keagamaan Islam yang dilaksanakan di Desa Tosari contohnya seperti safari Ramadan dan dakwah yang dilakukan oleh pondok pesantren. Dengan adanya pengaruh teknologi maupun agama tersebut, warga Tosari berhasil dalam Adaptation (adaptasi) atau penyesuaian dengan hal-hal yang baru.

Goal Attainment atau pencapaian tujuan dalam skema AGIL juga tercermin dalam pemaparan dalam proses adaptasi warga Tengger. Kemajuan teknologi mempengaruhi mata pencaharian di Desa Tosari. Tidak hanya dalam sektor pertanian, namun sektor ekonomi dan industri pariwisata juga meningkat.

\begin{tabular}{llll}
\hline Uraian Sumber Daya Manusia & Volume & Persentase \\
\hline \multicolumn{2}{l}{ Sumber penghasilan utama penduduk } & & \\
\hline a. & Pertanian, perikanan, perkebunan & 1.449 & $60.3 \%$ \\
\hline b. & Pertambangan dan penggalian & 10 & $0.4 \%$ \\
\hline c. & Industri pengolahan (pabrik, kerajinan, dll.) & 23 & $0.9 \%$ \\
\hline d. & Pedagang besar/eceran dan rumah makan/ Hotel & 175 & $7.2 \%$ \\
\hline e. & Angkutan, pergudangan, komunikasi & & \\
\hline f. & Jasa (Tukang batu/kayu) & 250 & $10.4 \%$ \\
\hline g. & Lainnya (air, gas, listrik, konstruksi, perbankan, dll.) & 63 & $2.6 \%$ \\
\hline h. & Pegawai Negeri & 24 & $1 \%$ \\
\hline i. & ABRI/ POLRI & 10 & $0.4 \%$ \\
\hline j. & Pensiunan & 6 & $0.2 \%$ \\
\hline k. & Lainnya/ Belum bekerja & 20 & $0.8 \%$ \\
\hline
\end{tabular}

Sumber: Profil Desa Tosari tahun 2017 
Islam menjadi agama mayoritas di desa Tosari mengindikasikan bahwa kegiatan dakwah yang dilakukan di Desa Tosari tercapai, terlihat dalam grafik di bawah ini.

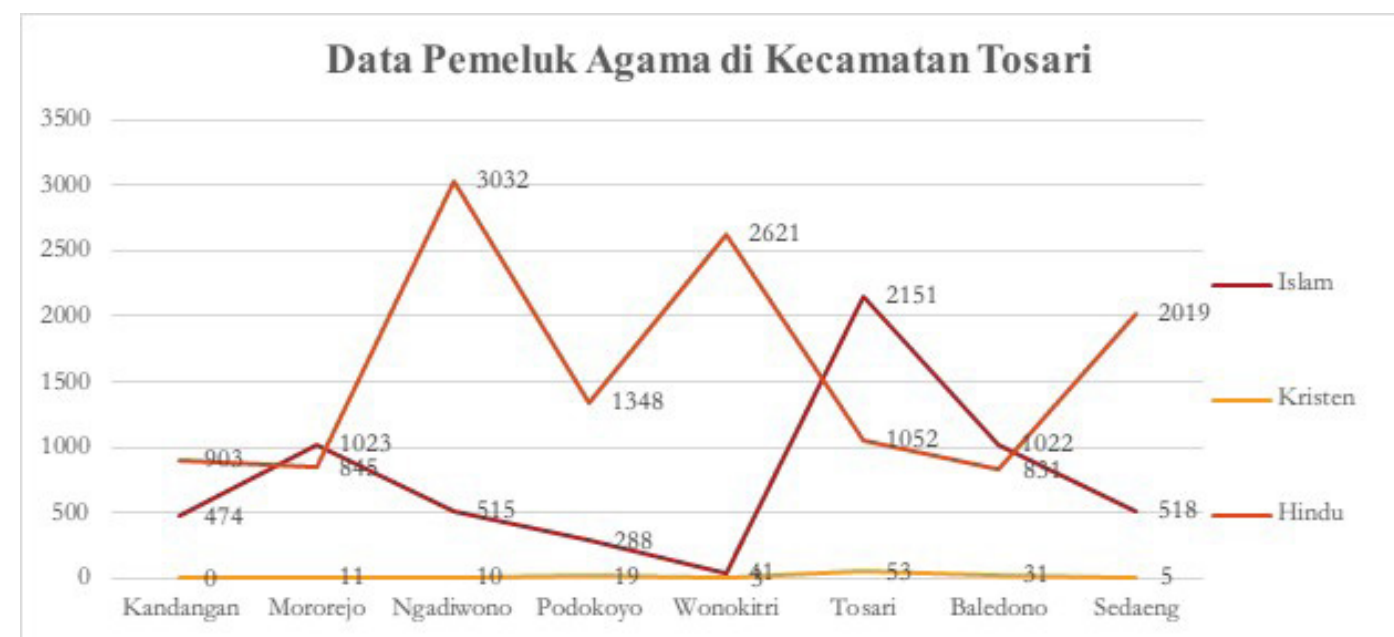

Sumber: Data Pemeluk Agama KUA Kecamatan Tosari Tahun 2018

Dalam Teori AGIL terdapat integrasi yang berperan dalam perubahan sosial. Integrasi merupakan sebuah sistem yang mengatur hubungan-hubungan yang menjadi komponen. Masyarakat Desa Tosari adalah masyarakat yang terbuka dengan warga pendatang hal ini menyebabkan mudahnya proses integrasi antara keduanya. Integrasi ini berlangsung antara warga Suku Tengger di Desa Tosari dengan pendatang. Pendatang berdatangan dengan berbagai tujuan. Seperti berdagang, berwisata, bahkan berdakwah. Integrasi terjadi dengan mudah karena adanya persamaan persepsi dan komunikasi. Banyak pendatang muslim yang sengaja berjualan di Desa Tosari, dengan demikian terjadi proses komunikasi melalui kegiatan jual beli antara keduanya. Proses komunikasi di sini menyebabkan pertukaran informasi yang dapat diperoleh antara komunikan. Dalam proses ini juga perubahan juga dapat terjadi, tergantung dengan individu mau menerima hal baru atau tidak. Ada pula pendatang yang menetap di Desa Tosari karena menikah dengan warga asli. Karena faktor ini pula banyak terjadi perubahan kepercayaan oleh warga asli Desa Tosari.

Pengaruh tersebut menyebabkan agama Islam berkembang pesat di Desa Tosari. Perkembangan ini juga dipengaruhi oleh adanya kegiatan dakwah yang dilakukan oleh masyarakat di luar Desa Tosari. Persebaran agama Islam di Desa Tosari dipengaruhi melalui organisasi Nahdlatul Ulama (NU) melalui lereng bawah dan secara perlahan masuk ke lereng tengah atau Desa Tosari. Tidak hanya karena organisasi muslim, proses penyebaran agama Islam pun terjadi karena pengaruh pedagang-pedagang kaya yang menetap di sana. Dengan demikian terjadilah integrasi kelompok. Jika integrasi kelompok berkembang, maka akan berkembang dengan meniadakan norma atau justru menciptakan nilai baru yang belum ada sebelumnya. Hal ini tercermin pada Penduduk Suku Tengger di Desa Tosari yang beragama muslim mulai tidak mempercayai adanya ritual adat yang dilakukan oleh Suku Tengger. Mereka melakukan ritual tersebut hanya sebatas menghargai kebudayaan saja, tidak meyakininya. Karena mereka meyakini bahwa segala sesuatu datangnya dari Tuhan YME.

Integrasi kelompok tidak hanya karena unsur kepercayaan. Pengaruh ekonomi juga menjadi salah satu faktornya. Perkembangan ekonomi dan industri pariwisata yang semakin maju menyebabkan perubahan pada warga Suku Tengger. Karena adanya kesibukan melakukan kegiatan ekonomi. Warga jarang melaksanakan kegiatan ritual Suku Tengger seperti pembuatan Gedhang Ayu yang seharusnya dilakukan setiap hari, dan juga upacara Barikan yang dilakukan sebulan sekali dalam rangka mengucap syukur bahwa selama sebulan mereka sudah diberi perlindungan. Kegiatannya pun bergeser, dari yang sebelumnya berbondong-bondong menuju sanggar untuk merayakan upacara Barikan, sekarang berganti menjadi menyumbang berupa material saja dan tidak pergi ke sanggar untuk mengucap syukur. 
Pemikiran Parsons mengenai AGIL yang terakhir adalah Latency (pemeliharaan pola). Latency ialah pemeliharaan pola sebuah sistem yang harus melengkapi, memelihara dan memperbaharui motivasi individu dan pola-pola budaya yang menciptakan dan mempertahankan motivasi tersebut. Pemeliharaan pola di Desa Tosari terlihat dari kemajuan ekonomi dan industri pariwisata di Desa Tosari memaksa warga menyesuaikan dengan keadaan lingkungan. Terdapat warga yang mengembangkan usahanya dengan bantuan teknologi seperti berdagang online. Dalam hal pariwisata, warga Desa Tosari juga mempunyai inisiatif untuk membuat penginapan bagi wisatawan yang datang. Komunitas hardtop juga menjadi unsur pola pemeliharaan, komunitas ini dapat menjadikan industri pariwisata di Desa Tosari berubah dan semakin berkembang. Dalam unsur kepercayaan pun juga terlihat pemeliharaan pola contohnya seperti adanya kegiatan kerohanian Islam yang diadakan rutin seperti safari Ramadhan

Dalam kasus ini terindikasi bahwa ada proses difusi dalam perubahan sosial yang terjadi melalui proses perpindahan agama dan kedatangan pendatang. Menurut Rogers difusi adalah penyebaran penemuan (inovasi) ke seluruh lapisan masyarakat atau ke dalam suatu bagian dari masyarakat ke masyarakat lainnya, difusi selalu menimbulkan perubahan budaya bagi yang menerima unsur kebudayaan lain yang menyebarkan itu (Sugiharja, 2013). Dalam hal ini penemuan yang dimaksud ialah ajaran agama Islam yang bagi masyarakat desa Tosari masih dianggap sebagai sesuatu yang baru.

Dalam proses difusi penyebaran agama Islam terdapat elemen-elemen yang menjadi pokok terciptanya tujuan penyebaran agama Islam. Menurut Rogers (1986) dalam proses difusi inovasi terdapat empat elemen pokok, yaitu suatu inovasi, dikomunikasikan melalui saluran komunikasi tertentu, dalam jangka waktu dan terjadi di antara anggota-anggota suatu sistem sosial.

1. Inovasi adalah gagasan, tindakan atau barang yang dianggap baru oleh seseorang. Dalam hal ini kebaruan inovasi diukur secara subjektif menurut pandangan individu yang menerima. Apabila dikaitkan dengan keadaan di desa Tosari hal yang dianggap inovasi adalah ide atau gagasan baru tentang agama Islam karena sebelum masuknya Islam, warga Tosari menganut agama Hindu. Ajaran agama Islam dianggap inovasi bagi masyarakat Desa Tosari yang dikomunikasikan secara positif.

2. Saluran komunikasi adalah alat untuk menyampaikan pesan-pesan inovasi dari sumber kepada penerima. Komunikasi dimaksudkan untuk memperkenalkan suatu inovasi kepada masa dan tersebar luas. Jadi saluran komunikasi yang digunakan dalam proses penyebaran agama Islam di desa Tosari adalah menggunakan media dakwah dimana media dakwah ini perlahan-lahan mampu mempengaruhi masyarakat di desa Tosari. Masjid dan Musala merupakan tempat yang mendukung proses dakwah. Selain itu pasar juga merupakan saluran komunikasi yang berpengaruh dalam perubahan budaya yang terjadi pada masyarakat di desa Tosari, karena pasar merupakan suatu tempat umum dimana bertemunya penjual dan pembeli yang memungkinkan terjadinya interaksi yang dapat mempengaruhi satu sama lain.

3. Jangka waktu tertentu adalah keputusan inovasi dari mulai seseorang mengetahui hingga memutuskan untuk menerima atau menolaknya. Pengukuhan terhadap keputusan tersebut berkaitan dengan dimensi waktu. Keinovatifan seseorang relatif bervariasi dalam menerima inovasi, dan dalam kecepatan pengadopsian inovasi dalam sistem sosial. Hal ini terbukti bahwa berdasarkan demografi jumlah penduduk penganut agama di desa Tosari pemeluk agama Islam tahun 2018 berjumlah 2.151 jiwa, hal itu menunjukkan bahwa masyarakat desa Tosari menerima inovasi tersebut. Masyarakat menyerap nilai-nilai yang ada dalam agama Islam, sehingga masyarakat menganggap bahwa mitos folklore dalam pemasangan Gedhang Ayu tidak sesuai dengan ajaran agama Islam karena di dalam upacara tersebut terdapat sesaji yang dianggap syirik dalam ajaran agama Islam. Sehingga mempengaruhi intensitas pelaksanaan upacara Gedhang Ayu di desa Tosari dan menyebabkan lunturnya folklore di dalamnya.

4. Sistem sosial merupakan unit yang berbeda secara fungsional dan terkait kerja sama untuk memecahkan masalah dalam rangka mencapai tujuan bersama. Dalam sistem 
sosial selalu terdapat norma, status, dan pemimpin yang penting dalam memahami nasib inovasi di dalam sistem sosial yang bersangkutan. Camping Ramadhan yang diadakan oleh pondok pesantren Sidogiri merupakan salah satu kegiatan yang dilakukan untuk mencapai suatu tujuan seperti berdakwah maupun mempertebal keimanan agama Islam. Pondok pesantren Sidogiri merupakan sistem sosial yang mempengaruhi perubahan sosial di Tosari.

Perkembangan agama Islam menyebabkan tumbuhnya pemikiran dalam berkehidupan yang didasari dengan ajaran Islam pada masyarakat. Salah satunya dalam pelaksanaan upacara adat Gedhang Ayu, mereka pada awalnya menganggap upacara Gedhang Ayu sebagai suatu keharusan dalam pelaksanaan ritual di wilayah Suku Tengger. Namun, saat ini setelah adanya pengaruh agama Islam pemikiran masyarakat tentang keharusan melakukan pemasangan Gedhang Ayu setiap hari mulai berubah. Pemikiran tentang melaksanakan perintah dan menjauhi larangan Tuhan Allah menjadi hal utama yang mengubah pandangan masyarakat terhadap pemasangan Gedhang Ayu. Cerita atau folklore yang berada di dalam Gedhang Ayu, sesaji, dan mantra merupakan hal yang dianggap tidak sesuai dengan ajaran agama Islam.

Dalam hal ini agama Islam merupakan penemuan berupa ide, gagasan, pola berpikir dan pola perilaku yang baru pada masyarakat Desa Tosari. Menjadikan agama Islam sebagai pertimbangan dalam segala aspek kehidupan. Yang akhirnya agama Islam juga mempertimbangkan untuk melakukan upacara adat Gedhang Ayu dan percaya terhadap folklore yang ada dan menjadi salah satu faktor dalam lunturnya folklore masyarakat Desa Tosari.

\section{Simpulan}

Lunturnya folklore masyarakat Suku Tengger terjadi karena adanya pengaruh gagasan baru yaitu agama Islam yang masuk ke dalam masyarakat tersebut. Pada awalnya warga Suku Tengger menjalankan ritual yang cenderung mengarah pada kepercayaan animisme dan hal ini tidak dilarang dalam kepercayaannya yaitu Siwa-Budha. Namun semenjak terjadinya konflik PKI pada tahun 1965, ada pengaruh dari agama Islam dan Hindu hal ini terjadi karena selain agama yang sah di Indonesia, maka akan dianggap sebagai aliran kepercayaan. Pada saat itu yang tidak memiliki agama dicap sebagai PKI. Dengan sebab ini timbullah pergantian kepercayaan dari yang mulanya aliran kepercayaan Siwa-Buddha menjadi Hindu, Islam, maupun Nasrani. Tosari menjadi desa Suku Tengger dengan penduduk muslim terbanyak dikarenakan adanya pengaruh dari lereng bawah yang mayoritas masuk organisasi Nahdlatul Ulama dan ada juga pedagang-pedagang muslim besar yang menetap di Desa Tosari. Pernikahan antara pendatang dan warga asli menjadi salah satu faktor warga masyarakat Suku Tengger di Desa Tosari tidak melakukan ritual, karena adanya ajaran baru yang dianut. Perubahan budaya warga Desa Tosari juga didukung oleh adanya sosialisasi yang dilakukan oleh pondok pesantren. Kebudayaan Suku Tengger yang mengarah pada alam dianggap tidak relevan dengan ajaran agama Islam yang dianut oleh masyarakat Desa Tosari. Ajaran agama Islam mempengaruhi kepercayaan warga terhadap folklore yang membentuk mitos yang ada. Agama Islam maupun Kristen tidak mempercayai adanya mitos yang mengarah pada suatu kepercayaan tertentu. Mereka melakukan kegiatan upacara adat hanya sebatas sebagai penghormatan kepada masyarakat lain yang meyakininya.

\section{Daftar Pustaka}

Acemoglu, D., Johnson, S., Robinson. I., Thaicharoen, Y. (2004). Institutional Causes. Macroeconomic Simptoms: Volatility. Crises and Growth. Journal of Monetary Economics, 50, 49-123.

Garna, J. K. (1992). Teori-teori Perubahan sosil. Bandung: Program Pasca Sarjana Universitas Padjadjaran. Lauer, Robert H. (2003). Perspektif Tentang Perubahan Sosial. Jakarta: Rineka Cipta

Nugraha, Hilman. (2015). Perubahan Sosial Dalam Perkembangan Pariwisata Desa Cibodas. Jurnal Sosietas 5 No.1. 
Indonesian Journal of Sociology, Education, and Development (IJSED) Vol. 1 Issue 2 Juli-Desember 2019

Puji Astuti, Nena, Dkk. (2017). Eksistensi Upacara Pernikahana Adat Walagara dalam Prespektif Perubahan Sosial dalam Pendidikan dan Pengelolaan Kebudayaan, (Surakarta: UNS Press)

Ritzer, G. (2012). Teori Sosiologi: Dari sosiologi klasik sampai perkembangan terakhir postmodern. Yogyakarta: Pustaka Pelajar, 11, 25.

Rogers, Everett M. (1986). Communication Technology: The New Media In Society. London: Collier Macmillian Publishers

Rosana, E. (2011). Modernisasi dan perubahan sosial. Jurnal Tapis: Jurnal Teropong Aspirasi Politik Islam, 7(1), 46-62.

Statistik, B. P. (2019). Jumlah kunjungan wisman ke Indonesia Desember 2018 mencapai 1,41 juta kunjungan. Dipetik September 3, 2019, dari BPS: https://www.bps.go.id/ pressrelease/2019/02/01/1543/jumlah-kunjungan- wisman-ke-indonesia-desember2018-mencapai-1-41-juta-kunjungan.html

Sugiharja, dkk. (2013). Perubahan Sosial Masyarakat Di Kaki Pegunungan Kendeng. Surakarta: UPT UNS Press. Suwantoro, Gamal. (2004). Dasar-Dasar Pariwisata. Yogyakarta: ANDI Yogyakarta

Tim Penyusun Kamus Pusat Pembinaan dan Pengembangan Bahasa, (1999). Kamus Besar Bahasa Indonesia. Jakarta: Balai Pustaka 